\title{
Tópicos de Derecho: En torno al ejercicio de la Abogacía
}

\author{
por el Dr. CERLOS RODRIGUEZ PASTOR, \\ ex-Ministro de Educación Pública, \\ Y Catedrático Titular de Derecho Romano (P.U.C.)
}

El vocablo "tópico" (del griego topos: lugar) tiene dos acepciones: una vulgar y otra erudita. Vulgarmente, tópico es sinónimo de lugar común, quizá más propiamente de expresión "trivial", no en cuanto susceptible de tomarse como algo intrascendente, fútil, insubstancial, falto de novedad, carente de originalidad o que no sobresale de lo ordinario; sino más bien, como referencia al "trivio" o sea a las tres vías o ramas que antiguamente integraban las tres artes liberales conectadas con la Elocuencia, a saber: La Gramática, la Retórica y la Dialéctica, En este sentido, un "tópico" aun vulgarmente considerado no es tan trivial como pudiera parecer.

Desde el punto de vista erudito, los "tópicos" son los lugares dialécticos que, según Aristóteles, constituían aquellos principios de donde se extraen los elementos o razones que han de servir para convertir lo dudoso en racional. En esta acepción los tópicos se reducen a definir, a dividir, a exponer el género próximo, a enunciar las diferencias específicas, a enumerar los accidentes de las cosas. Responden a estos interrogantes fundamentales: QUE; CUANTO; DE DONDE; COMO.

Discurriendo extensivamente, tratar de TOPICOS DE LA ABOGACIA equivaldrá a planteor aqueilas cuestiones que interesan respecto al ejercicio de nuestra ocupación profesional. Qué es; cómo se diversifica; sobre qué fundamentos se sustenta; de qué manera funciona. Conceptúo que, de momento, hay un tópico por analizar, en torno a nuestra actividad de abogados que es el relacionado con la Oratoria Forense.

Si nos atenemos al origen etimológico y al valor semántico de las distintas denominaciones que se aplican a nuestra profesión, el "abogado" (de ad-vocatus), es el "llamado", porque en Roma los jurisconsultos o expertos en Derecho eran requeridos a prestar el auxilio de su consejo en las cuestiones difíciles, en los asuntos complejos, en los problemas escabrosos que se proponían a su consideración. Se les denominaba también "patronos", por analogía con la función patronal que el "dominus" cumplía con sus libertos (derecho de patronato), o el patricio con su clientela. Aun hoy es usual decir que las causas de nuestros clientes han sido puestas bajo nuestro patrocinio. Las Siete Partidas consideraron a los abogados como "oradores o voceros" (de os-oris, voz) ya que la defensa suele hacerse verbalmente o de viva voz. En el Derecho Canónico recibieron el nombre de 
"postulantes o postuladores"", pues su misión es pedir lo que corresponde en justicia. "Intercesores" fue la denominación que les dió el Derecho Germano, porque los abogados nos interponemos entre el cliente y el magistrado, aludiendo, quizá a la "intercessio" que en el Derecho Romano servía para garantizar $\alpha$ un deudor y que, por virtud del Senado-Consulto Veleyano fue vedada a las mujeres, pues la intercesión constituía un oficio masculino, ("officium virile").

De todos modos; cualquiera que sea la nomenclatura que se escoja. "Llamados", "Oradores", "Voceros", "Postuladores": "Patronos", "Intercesores", el abogado es la persona a la que un título profesional premune y autoriza para defender a sus clientes, fundamentalmente ante los Tribunales. Esta defensa, desde luego, debe ser predominantemente oral. Pongo énfasis y subrayo la expresión de las Siete Partidas: ORADORES: "Orabunt melius causas" reza el lema de nuestra Orden, porque parece que la oralidad es esencial, inherente, casi precisiva a nuestra profesión. Quizá el Egipto fue el único caso en que se prohibió la defensa de viva voz, para evitar que los abogados, abusando de sus recursos oratorios, sedujesen a los jueces en desmedro de la justicia. Remedio de la venalidad a que fueron proclives ciertos oradores, fue en Roma la "Ley Civicia".

Quiere decir entonces que el abogado, al menos en cuanto defensor ante los Tribunales, es un orador, que se dirige verbalmente $\alpha$ los jueces, cumpliendo los esenciales objetivos de toda elocución; para persuadirles, como escribía Milá y Fontanals; o para imprimir con calor y eficacia en el ánimo de su auditorio los sentimientos de que él mismo está poseído, según sostenía Capmany; o en una actitud polémica, para tratar de hacer fuertea las razones débiles y débiles las fuertes como sugería Ortega y Gasset; o simplemente hablando de manera que se consigan los fines ínsitos en la palabra, como lo proponía Blair.

Por eso, nuestra misión como defensores en los estrados judiciales consiste en ilustrar la inteligencia de los jueces y en conmover su voluntad para que sus resoluciones coincidan o al menos se aproximen, con la exigencia de justicia, con el postulado de legalidad o con la pretensión de verdad que debemos poner en la tesis propugnada al ejercitar la defensa y se alejen en igual grado de las aseveraciones del abogado contrario. En otros términos: no es posible desarticular el ejercicio de la abogacía de la elocución oral. Un notable jurista y ex-magistrado argentino ha escrito con cabal acribia: "si mi experiencia de abogado me enseñó que la comunicación de los elementos humanos que intervienen en un litigio o proceso es garantía de justicia; ahora, después del ejercicio de mi renunciada magistratura, reafirmo aun más y como principio absoluto, la necesidad de implantar la oralidad". (1).

La oratoria forense funciona con sujeción a ciertos presupuestos esenciales. De un lado debe correr parejas con el profundo dominio que de su profesión ha de tener el abogado. El más brillante discurso resulta estéril $e$ infecundo; se reduce $\alpha$ inane verbalismo, vacía logomaquia y huera tautología cuando no va acompañado de conocimientos densos y amplios

(1) Enrique Díaz de Guijarro, "Abogados y Jueces", pág. 48. Abeledo_Perrot, 1950. Buenos Aires. 
sobre las cuestiones generales del Derecho y sobre los problemas específicos. materia del debate. Es verdad que el título que nos otorga la Universidod, después de satisfechas las pruebas reglamentarias, confiere una presunción de capacidad. Pero es sólo una "presumptio juris". Significa nada más que un cartón desprovisto de contenido, si quien lo ostenta carece de la ciencia necesaria y no mantiene vigentes sus conocimientos, refrescándolos $e$ incrementándolos continuamente con el estudio cotidiano y la dedicación indeficiente, exigibles no sólo para el desempeño de la abogacía cuyas funciones formales $\mathrm{y}$ extrínsecas se cumplen en los Juzgados y Tribunales, planteado ya el litigio; sino también mediante el consejo oportuno, la advertencia adecuada, la consulta previa, el dictamen experimentado, la orientación conveniente, la opinión precisa, el parecer sagaz, formas subyacentes en nuestra actividad profesional y que se ejercitan para impedir que surja la controversia.

Así queda circunscrito y delimitado el doble ámbito dentro del cual se polariza nuestra profesión. Uno, previo, anterior al juicio en el que predomina el jurista; otro, posterior y subsiguiente en el que prevalece el abogado. Son las dos etapas análogas a la Profilaxia y a la Terapéutica en el campo de la Medicina: la que previene y la que remedia. En determinados casos, la función consultiva deberá preferirse a la defensiva. Pues, como muchas voces es mejor prevenir que curar, así en ocasiones más vale evitar un juicio que defenderlo. Tan abogado es el que previene los litigios, como el que los defiende una vez producidos. Así ha sido siempre. En Roma, el "prudens" era el que absolvía previamente las consultas que se le formulaban, sobre cuestiones genéricas, ejercitando el "jus publice respondendi". Fn cambio el Abogado, bajo $\epsilon 1$ nombre de "causiducus" era el que, ante el Magistrado defendía el caso concreto. Ambas categorías corresponden a las que, dentro del Derecho Inglés, están representadas por los "sollicitors" y por los "barristers", es decir, por los consultores $Y$ por los abogados propiamente tales.

En una y otra esfera se requiere como condición "sine qua non" $\theta$ insustituíble, de la ciencia, cuyo presupuesto es precisamente el título del que nos premune la Facultad. Empero, la capacidad teórica y doctrinaria debe ser complementada con el estudio, asiduo, indeclinable, tenaz y perseverante. Cicerón en su libro "De Oratore" expone cómo debe trabajar el Abogado, en el estudio, en la dirección, en el análisis, en el escudriñamiento de cada uno de los asuntos que se le encomiendan, a fin de alcanzar el éxito propuesto. Recuerdo haber leído en una obra de Francis Wellman, miembro del Foro de New York, intitulada "Cómo ganar juicios", que la palabra maestra que remueve todos los obstáculos; el verbo mágico que obra pasitivos milagros, es el trabajo. El malogrado profesor uruguayo Eduardo Couture, sintetizó en los cuatro primeros preceptos del Decálogo que redactó, al ser incorporado en el Colegio de Abogados de Buenos Aires, este aspecto de nuestra actividad profesional. $1^{\circ}$ Estudia, pues, el Derecho se transforma constantemente, y sino sigues sus pasos, serás cada día menos abogado; $2^{\circ}$ Piensa porque el Derecho se aprende estudiando pero se ejercita pensando; $3^{\circ}$ Trabaja porque la Abogacía es una ardua fatiga al servicio de la Justicia; $4^{\circ}$ Lucha por el Derecho, empero el día en que encuentres en conflicto el Derecho con Justicia, lucha por la Justicia. 
Yo no sé de ningún abogado que piense, estudie, luche y trabaje que no haya triunfado en su profesión. No en vano, el lugar donde despachamos y atendemos a nuestra clientela recibe el nombre de "estudio", porque en el bufete, el abogado aplica su inteligencia, sopesa el pro y el contra, investiga con acuciosidad, esmera y a conciencia el fondo de los asuntos sometidos $\alpha$ su patrocinio.

Pero todos estos requisitos, que podríamos llamar de índole intelectual, como la ciencia, el conocimiento, el estudio, la investigación, deben estar acompañados de una cualidad ética insobornable que es la probidad. Catón dió del orador una definición que no ha sido superada: "Vir probus, dicendi peritus". Varón honesto, experto en el buen decir. Este concepto puede muy bien aplicarse al abogado que es un orador por ontonomasia. El jurista Couture, antes citado, ha escrito que la abogacía es un constante ejercicio de la virtud; que la tentación pasa siete veces al día por delante del abogado y que éste puede hacer de su cometido la más noble de todas las profesiones, pero también el más vil de todos los oficios. Un abogado deshonesto que acoje las malas causas y los pleitos turbios a sabiendas de su ilegalidad substancial; un abogado infidente con su propia clientela; un abogado desleal para con la parte contraria y para con el juzgador; que recurre a las argucias y a los subterfugios; a las trapisondas, chicanerías y triquinuelas; incurriendo en lo que podría denominarse "demagogia forense"; un abogado que sólo trata de complicar, tergiversar, y deformar los hechos; extraviar el criterio de los jueces y empantanar el proceso, estó desvirtuando las esencias de la profesión que consiste en actuar al servicio de la justicia. Podemos tal vez equivocarnos en los aspectos técnicos del problema que se nos ha encomendado, pese a nuestros conocimientos y a nuestra dedícación, puesto que nadie disfruta de la infalibilidad. Podemos resultar envueltos de buena fe en las brumas del error, ya que no siempre la luz de la verdad está a nuestros alcances. En lo que no debemos caer jamás, es en la deshonestidad. Si carecemos del derecho de convencer por la injusticia intrínseca de las causas patrocinadas, tampoco estaremos facultados para intentar persuadir, echando mano de recursos oratorios vedados, toda vez que la persuación no es sino el trampolín para saltar hacia el convencimiento.

Hay más todavía. La moralidad en el desempeño de la abogacía debe estar respaldada por la buena fama, reflejo de una conducta intachable que se proyecta inexorablemente sobre nuestra actividad profesional. Jamás podrá el orador forense, persuadir y convencer a los jueces si éstos conocen la antinomia entre el dicho y el hecho; si están cerciorados de la inconciliable dislocación entre nuestras palabras y nuestro comportamiento, y si saben que hay profunda inadecuación entre la tesis que propugnamos y la conducta que observamos.

Finalmente, el abogado, si ha de ser un orador forense, sobre las cualidades intelectuales y éticas que le son imprescindibles, deberá ser experto en las reglas y en los recursos de la Oratoria. La Oratoria es un arte: es una técnica. En toda pieza forense hay que distinguir el fondo $y$ la forma. El fondo se refiere a lo que hay que decir. La forma a cómo hay que decirlo. El fondo está constituído por la cultura jurídica del abogado. La forma, por el lenguaje que es el instrumento a través del cual se expresa 
la cultura. Si el abogado, por desconocimiento de la doctrina; por ignorancia de la ley, por no estar empapado en la esencia del problema que se controvierte, no tiene nada qué decir, su discurso se reducirá a una sucesión de palabras hueras. Sonarán simplemente como un "flatum vocis". Ni persuadirá, ni convencerá $\propto$ los jueces. Por brillantes que sean sus cualidades rigurosamente oratorias, la defensa culminará probablemente en un rotundo tracaso.

En cambio, por amplio que sea su conocimiento de las leyes; por profunda que sea su ciencia jurídica; por versado que esté en el asunto que se debate, si carece de aptitudes oratorias, estará expuesto a dar una penosa impresión de su defensa. Sus argumentos serán subestimados y sus puntos de vista aparecerán deleznables e inconsistentes. No encontrarán eco en el ónimo de los jueces.

De allí la necesidad de que la forma corresponda al fondo y de que el discurso se estructure conforme $\alpha$ un plan previo; se desarrolle en un estilo conveniente y se exprese de modo que la elocución y el gesto sean los más congruentes a la materia tratada y a los objetivos fundamentales perseguidos por el abogado. Lo ideal es acordar el contenido a una elocuente forma expresiva, a través de la cual la densidad doctrinaria adquiera la más adecuada resonancia.

Nadie ignora las partes en que se desarticula un tiscurso según la Retórica clósica: exordio; proposición; división; narración; confirmación; refutación y peroración. Aristóteles las redujo a la proposición y a la confirmación, ya que las demás pueden perfectamente refundirse en alguna de ellas. De todos modos; desde el preámbulo hasta la recapitulación; desde el exordio hasta la peroración; desde el arranque inicial hasta la meta final, el abogado en el desarrollo de su discurso debe sujetarse a un esquema lógico; debe usar un estllo, no sólo gramaticalmente correcto, sino en ocasiones engalanado por el brillo de las imágenes, por el esmalte de las figuras literarias $\mathrm{y}$ por los depurados resortes del arte. Debe por último modular con eufonía y elegancia, accionar con gestos expresivos y convincentes, de suerte que la voz y la actitud, resulten sobrias sin monotonía; dinámicas sin atropellamiento ni precipitación; huyendo siempre del amaneramiento de la afectación, de la pedantería y del patetismo exajerado. Utilizará en ocasiones los recursos de una aguda y sutil ironía, pero sin degenerar en la insidia o en la diatriba. Pondró en suma, en los pasajes culminantes de su discurso, el móximo de calar, de vehemencia y de emoción, notas que son concomitantes al convencimiento de la propia verdad y a la firmeza ínsita en la tesis que se defiende. No olvidemos que tendrá que resignarse a entregar al fuego sus discursos, aquel orador que no haya puesto en ellos algo de su llama interior y de su calor espiritual.

Pues bien; todo esto supone reglas, recursos, práctica; disciplina; aprendizaje; técnica. Se ha escrito que el poeta nace y que el orador se hace. "Poeta nascitur; orator fit", reza el adagio latino. Y ello es cietto, siempre sobre el supuesto de que concurran ciertos dones congénitos, imputables desde luego a la generosidad de la Providencia, pero sin los cuales no es posible llegar $\alpha$ dominar la Oratoria. De allí que tendrá que renunciar a destacarse como un orador forense quien carezca de una inteligencia 
por encima del nivel común de las gentes; quien no posea una memoria firme y rápida; quien esté desprovisto de una imaginación fértil $\mathrm{y}$ vivaz; quien no tenga espíritu generalizador, criterio analítico, aptitud metódica $Y$ facilidad elocutiva.

Lo que ocurre es que todas estas cualidades nativas, han de desarrollarse, ejercitarse, cultivarse, desenvolverse, enriquecerse $y$ fecundizarse con el estudio asiduo de las reglas oratorias, con la próctica constante de hablar en público; con el hábito de escuchar a los grandes oradores y con la lectura frecuente de los mejores modelos.

Cuántos sabios eminentes sólo han logrado dominar el difícil arte de la palabra hablada, a costa de enormes sacrificios. Demóstenes, por ejemplo, por su tartamudez, por la pobreza de su estilo, por sus defectos físicos, suscitó hilaridad al pronunciar sus primeros discursos. Pero $\alpha$ fuerza de trabajo sistemático, de estudio tenaz y de severa autodisciplina, llegó a convertirse en el más famoso orador de Grecia y en uno de los más ilustres de la humanidad. El mismo Cicerón, la más gigantesca luminaria de la literatura romana, dedicó varios años al aprendizaje de la oratoria, al lado de sus grandes maestros.

Se ha sostenido en ocásiones que los jueces y magistrados, por la profundidad de sus conocimientos jurídicos, por su versación acerca de los dispositivos legales; por su experiencia en el discernimiento de la justicia, se mantienen impasibles e invulnerables al impacto de los discursos de los abogados; por lo que la Oratoria resulta inútil, superflua, innecesaria y hasta contraproducente. Ojalá que esto fuese siempre cierto. Pero las cuestiones de hecho $y$ de deprecho contenidas en los juicios; los problemas que se debaten en los estrados judiciales, son a veces tan complejos, tan enmarañados, tan difíciles, que nadie más que los juzgadores requieren suficientes elementos de convicción que los abogados ponen a su disposición en sus informes orales, pronunciados con arreglo a la técnica de la oratoria forense. Así los jueces procuran en sus tallos hacer que triunfe la justicia. Empero, al logro de esta victoria, colaboran eficientemente los abogados, quienes en trase de Héctor Lafaille, resultan los soldados desconocidos de la jurisprudencia.

En síntesis, el abogado, en el desempeño de su función de defensor, es ante todo un orador. Por ello, debe reunir cualidades intelectuales $Y$ éticas sobresalientes; algunas congénitas y naturales; pero otras adquiridas y vigorizadas con el estudio, con la dedicación y el trabajo. Aun las dotes nativas deben ser esmeradamente cultivadas $y$ desarrolladas a base de la técnica y de las prácticas oratorias.

De lo expuesto, deslizándonos como por sobre un plano indicado, liegamos a una conclusión lógica e insoslayable: la conveniencia de restablecer en el Pensum de los estudios facultativos, la asignatura de ORATORIA FORENSE, dictada desde luego, con arreglo a criterios metodológicos reactualizados, de acuerdo con las inspiraciones de una concepción moderna y con sujeción a una técnica renovada. Quede esta conclusión como una semilla echada en el surco de la inquietud intelectual que tanto distingue $a$ las autoridades universitarias, a fin de que, meditando sobre ella, decidan si vale la pena que florezca y fructifique. 